of the value of the brilliant discoveries of our days" made by the eminent palæontologists cited by Beecher, or by that distinguished investigator himself.

Sv. Leonk. Törnquist.

Lund, September, 1896.

ANGLESEY AGGLOMERATES.

SrR,-In his short paper in your current (November) ${ }^{1}$ number, Sir A. Geikie is very ready to give up his opinion as to the agglomeratic character of certain fragmental rocks in Anglesey, but I hope my own opinion was based on too solid a foundation to be so easily overthrown. After reading this retractation, I turned to Sir A. Geikie's and my own original description of these agglomerates, quoted below, and it appeared to me at once that if the phenomena in the Isle of Man were the same as in Anglesey, the rocks in the former locality could not be "crush-conglomerates." I therefore turned again to the description of these "crushconglomerates" as given by Mr. Watts, and this is what he says:"The fragments exhibit a great uniformity in composition, and nothing has bitherto been found in them but grits and slates," which "could all be matehed either in the transition series or else in the main grits and slates" (between which the crush has taken place). "Although Mr. Lamplugh was alive to the importance of looking out for the existence of fragments of igneous rocks and other strangers, and collected a number of specimens to be tested with this point in view, not a single fragment of any other rock bas up to the present been detected." 2

We cannot doubt that Sir A. Geikie is equally alive to the importance of this feature, and, indeed, his new descriptions of the rocks in Anglesey indicate as much, but I think in his enthusiasm he must have forgotten bis older, fuller, and, I think, more accurate account of them. This is what he first said about the rocks at Llangrefni : "The agglomerates ... contain abundant blocks of reddish quartzite, pieces of various felsites and of finely amygdaloidal andesites." 3 My own statement is practically identical: "They contain huge masses of quartzite and igneous rocks." 4 These are certainly not descriptions of the rocks of the neighbourhood between which the crushing conld have taken place. Sir A. Geikie now writes: "The strata affected appear to have been originally shales or mudstones (with possibly some fine felsitic tuffs), alternating with bands of hard siliceous grit." 5 These two descriptions are very different. Can Sir A. Geikie reconcile them ?

Of the rocks near Cemmaes he originally wrote (of the vent on Mynydd Wylfa) : "It is filled with a coarse agglomerate, among the large blocks in which fragments of quartzite, limestone, felsite, grit, and shale may be noticed" (five varieties of rock); and the vent on the west side of Cemmaes harbour "appears to have been drilled

I Geol. Mag., Dec. IV, Vol. III, p. 481.

2 Q.J.G.S., vol. li, p. 591.

3 Ibid., vol. xlvii, p. 130 .

4 Ibid, vol. xliv, p. 487.

5 Geol. MaG., Dec. IV, Vol. III, p. 481. 
through some of the thick limestone bands of the district. Large masses of vertical and crumpled limestone beds, as well as quartzite, have been caught up in the agglomerate, together with abundant blocks of grit, fragments of shale, and pieces of a pale felsite" ${ }^{1}$ (ive varieties again). Of the vent at Porth Cenal my own description is : "The most remarkable feature is the occurrence of great quartz lumps, which are of all sizes and shapes, and lie promiscuonsly in an agglomerate of slates, grit, and dust," and, " in the headland of Pen-y-pare we get another agglomerate of quartz lumps and ash"; and, after observing that these rocks (the limestone not being mentioned as being merely torn from the sides of the vent) are not those of the immediate neighbourhood, I added: "We cannot here refer [these agglomerates] to the action of a crush-fault," ${ }_{2}$ a remark which shows that I was not unaware of this alternative. These descriptions, with the interchange of "felsite" and "ash," are fairly consistent, but Sir A. Geikie's new description is: "The huge blocks of limestone, there to be seen isolated among fragmentary grits and slates, are referable to the disruption of some of the limestone bands which occur abundantly in the neighbourhood" (quite so). "A gradation may be traced from the slates and grits outside the areas of more severe dislocation into the intensely crushed and sheared "agglomerate." " Where is bere the quartzite, and the felsite, and the drilling?

The fact is that one main reason, amongst others, in my mind at least, for calling these Anglesey masses agglomerates, was the occurrence in them of a variety of rocks not like those of the immediate neighbourliood; while the main reason for believing the Manx rocks to be "crush-conglomerates" is that the rocks in them are of those kinds only which occur on either side of the area of crushing. The phenomena in the one case are, therefore, not the same as those in the other.

November 4, 1896.

\section{THE OLD RED SANDSTONE OF SCOTLAND.}

Sir,-- Regarding the statement of Professor Davis in last month's issue of this Magazine, it gives us great pleasure to receive his explanation that the terms Devonian and old Red Sandstone had been used synonymously in his paper, and not as representing two distinctly different conditions of deposit. But he must be well aware that this loose application of these two terms has long fallen into disuse in British geology, and that they now stand for two different types of deposit. Hence it was quite natural for anyone rearing his footnote to suppose that his "I)vonian erosion" refers to his notice of Sir A. Geikie's plain of marine denudation given in the body of the paper; while his reference to the Old Red Sandstone stands for something quite distinct. Further, as he says himself, having been principally indebted to "English writings" for his knowledge of the structure of this country, we thought it

1 Q.J.G.S., vol. xlvii, p. 134.

2 Ibid., vol. xliv, pp. 517-8.

3 Geol. Mag., Dec. IV, Yol. III, p. 482. 